\title{
Application of Pyrazole Derivatives As New Substitutes of Auxin IAA To Regulate Morphometric and Biochemical Parameters of Wheat (Triticum Aestivum L.) Seedlings.
}

\author{
Tsygankova V.A.*, Andrusevich Ya.V., Shtompel O.I., Kopich V.M., Panchyshyn S.Ya., Vydzhak R.M., Brovarets \\ V.S. \\ Department for Chemistry of Bioactive Nitrogen-Containing Heterocyclic Compounds, V.P. Kukhar Institute of \\ Bioorganic Chemistry and Petrochemistry, National Academy of Sciences of Ukraine, 1, Murmanskaya str., \\ 02660, Kyiv, Ukraine \\ vTsygankova@ukr.net
}

\begin{abstract}
The comparative analysis of plant growth regulating the activity of new synthetic low molecular weight heterocyclic compounds, pyrazole derivatives, and auxin IAA ( $1 \mathrm{H}$-Indol-3-ylacetic acid) was conducted. It was shown that the synthetic compounds used at the concentration $10^{-8} \mathrm{M}$ revealed stimulating auxin-like and cytokinin-like effects on growth and development of wheat (Triticum aestivum L.) seedlings cultivar Antonivka during the six weeks. The morphometric parameters of the $6^{\text {th }}$-week-old wheat seedlings grown in the water solution of the pyrazole derivatives used at the concentration $10^{-8} \mathrm{M}$ were similar or higher to the morphometric parameters of the wheat seedlings grown in the distilled water (control) or water solution of auxin IAA used at the same concentration $10^{-8} \mathrm{M}$ on average: to $31-54 \%-$ for total number of roots, to $39-$ $104 \%$ - for total length of roots, to $53-66 \%$ - for length of the longest root. The content of photosynthetic pigments in the leaves of the $6^{\text {th }}$-week-old wheat seedlings grown in the water solution of the pyrazole derivatives used at the concentration $10^{-8} \mathrm{M}$ increased on average: to $15-34 \%-$ for content of chlorophyll a, to $10-61 \%$ - for content of chlorophyll $b$, to $16-34 \%$ - for content of chlorophylls $a+b$, to $14-28 \%-$ for content of carotenoids, as compared with content of photosynthetic pigments in the leaves of the wheat seedlings grown in the distilled water (control) or in the water solution of auxin IAA used at the same concentration $10^{-8} \mathrm{M}$. The obtained results confirmed the possibility of the practical application of pyrazole derivatives as new effective substitutes for plant hormones for regulating the growth and development of wheat (Triticum aestivum L.) plants during the vegetative stage.
\end{abstract}

Keywords: Triticum Aestivum L., IAA, Pyrazole Derivatives, Plant Growth Regulation.

\section{Introduction}

Today, a new promising strategy for plant growing is developing of environmentally friendly plant hormones and plant growth regulators [1 - 17], natural bio stimulants or biofertilizers [18 - 23] that are capable of accelerating the growth and development of plants, reducing the phytotoxicity of chemical agents, and enhancing the plant immune response to abiotic and biotic stresses [1, $24-27]$.

In this regard, the elaboration of new effective ecologically safe plant growth regulators on the base of synthetic low molecular weight heterocyclic compounds is a very strategic approach. As is known, the various classes of low molecular weight heterocyclic compounds, derivatives of pyrimidine, pyrazole, and oxazole are widely applied in the agriculture as plant growth regulators, herbicides, fungicides and antibacterial agents [28 - 35].

The advantage of application of synthetic low molecular weight heterocyclic compounds is their high efficiency at their application at very low concentrations and ecological safety due to lack of toxic effect on the human, animal and plant cells; moreover they are widely used in the medical practice as therapeutic agents for treatment of nervous, allergic, gastroesophageal, cancer, bacterial, viral, fungal, infectious, and inflammatory diseases [36 - 44]. 
Wheat (Triticum aestivum L.) is the major strategic cereal crop cultivated over the world [45 - 47]. Wheat provides by $30 \%$ of the food calories consumed by world population $[46,47]$. Wheat seeds contain bioactive compounds that are important to the pharmaceutical industry: alkaloids, saponins, glycosides, terpenoids, steroids, flavonoids, and tannins [48]. Wheat is used as a raw material for the production of malt and beer [47]. However, despite the rapidly increasing of wheat sowing, there are significant problems with the increasing of the productivity of this crop because the world population is expected to reach 9.7 billion people by 2050 [49]. Abiotic and biotic stress-factors hurt the vegetative growth of wheat, thereby reducing plant productivity [25]. The plant growth regulators and fertilizers are used to accelerate the growth of wheat plant during the vegetative stage and increase crop yields [52 - 54].

As is known the main disadvantages of the practical application of traditional plant growth regulators are low growth regulating activity when used at high concentrations, their storage instability, and toxicity to humans, animals and environment [55 - 57]. In addition, excessive use of chemical agents of plant protection and mineral fertilizers leads to a number of negative consequences: the formation of resistant races of pathogens which cause plant diseases; depletion of the quantitative and qualitative composition of soil microbial coenoses, mainly due to the reduction in the number of beneficial members of soil microbiota; accumulation of toxic residues in the environment [58-61].

At present, various classes of synthetic low molecular weight heterocyclic compounds are synthesized at the Institute of Bioorganic Chemistry and Petrochemistry of National Academy of Sciences of Ukraine as new plant growth regulators. Our numerous studies have shown that chemical compounds belonging to derivatives of pyridine, pyrimidine, and pyrazole revealed a high stimulating effect on seed germination and growth of seedlings of various crops [62 - 69]. Since synthetic low molecular weight heterocyclic compounds are applied at very low non-toxic for human, animal and plant concentrations $10^{-8} \mathrm{M}-10^{-9} \mathrm{M}$, it is possible to prevent the negative effects on environmental pollution in comparison with chemical agents and plant growth regulators currently used in high concentrations and to have a significant half-life [55-61]. Therefore, the great theoretical and practical interest is an elaboration of new effective and environmentally friendly plant growth regulators on the base of synthetic low molecular weight heterocyclic compounds to intensify the vegetative growth of wheat.

This work is devoted to studying of the stimulating effect of synthetic low molecular weight heterocyclic compounds, pyrazole derivatives on growth and development of wheat (Triticum aestivum L.) seedlings cultivar Antonivka during the vegetative stage.

\section{Materials and Methods}

\subsection{Chemical structure of pyrazole derivatives and plant hormone auxin used for bioassays}

We conducted a comparative analysis of the plant growth regulating the activity of new synthetic low molecular weight heterocyclic compounds (LMWHC), pyrazole derivatives (compounds № 1-7) and plant hormone auxin IAA (1H-Indol-3-ylacetic acid) (Table 1).

Table 1. The chemical name, structure and relative molecular mass of plant hormone auxin IAA and synthetic $\mathrm{LMWHC}$, pyrazole derivatives

\begin{tabular}{|l|l|c|}
\hline Ccompounds & $\begin{array}{c}\text { Chemical structure of } \\
\text { compounds }\end{array}$ & $\begin{array}{c}\text { Chemical name and relative molecular mass } \\
\text { of compounds }\end{array}$ \\
\hline IAA & $(1 H$-Indol-3-yl)-acetic acid; \\
\hline
\end{tabular}




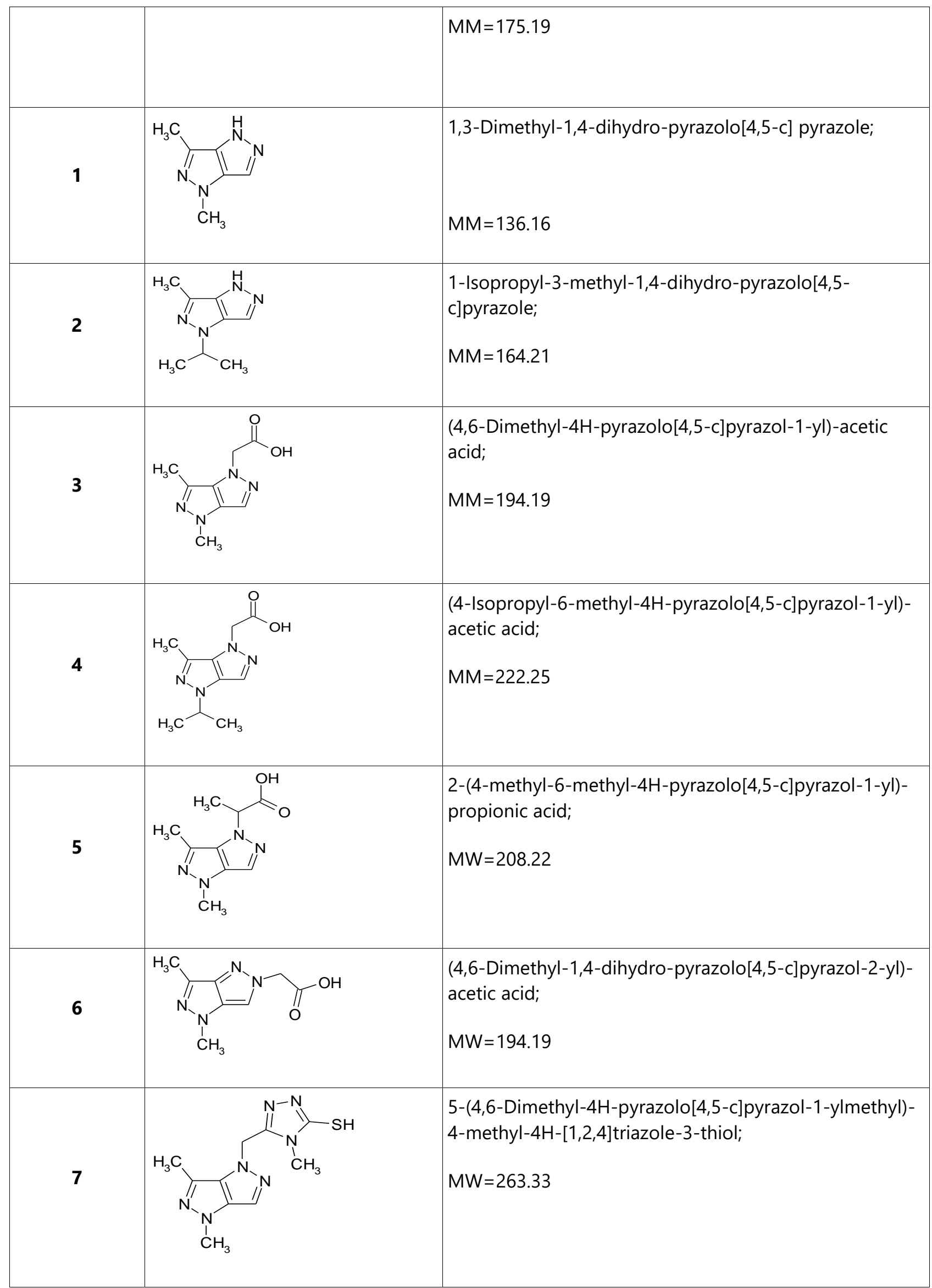




\subsection{Plant Treatment and Growing Conditions}

Seeds of wheat (Triticum aestivum L.) cultivar Antonivka were surface sterilized by $1 \% \mathrm{KMnO}_{4}$ solution for $5-10$ min followed by treatment with $96 \%$ ethanol solution for $1 \mathrm{~min}$, and then washed three times with sterile distilled water. After this procedure seeds were placed in the cuvettes (each containing 25-30 seeds) in perlite moistened with distilled water (control), or with the solutions of synthetic LMWHC, pyrazole derivatives used at the concentration $10^{-8} \mathrm{M}$, or plant hormone auxin IAA (1H-Indol-3-ylacetic acid) used at the same concentration $10^{-8} \mathrm{M}$. Afterward, wheat seeds were placed in the thermostat for germination in the darkness at the temperature $23{ }^{\circ} \mathrm{C}$ during 48 hours. Sprouted wheat seedlings were placed in the growth chamber where seedlings were grown for six weeks at the $16 / 8 \mathrm{~h}$ light/dark conditions, at the temperature $24-25^{\circ} \mathrm{C}$, light intensity 3000 lux and air humidity $60-80 \%$. The comparative analysis of the morphometric parameters of wheat seedlings (length of shoots ( $\mathrm{mm}$ ), total number of roots (pcs), total length of roots $(\mathrm{mm})$, and length of the longest root $(\mathrm{mm})$ was carried out at the end of the $6^{\text {th }}$ week after seed germination according to the guideline [70].

\subsection{Determination of Content of Photosynthetic Pigments in The Leaves of The Wheat Seedlings}

The content of chlorophyll a, chlorophyll b and carotenoids was determined in the leaves of the $6^{\text {th }}$-week-old wheat (Triticum aestivum L.) seedlings cultivar Antonivka grown either in the distilled water (control), or in the water solution of synthetic $L M W H C$, pyrazole derivatives used at the concentration $10^{-8} \mathrm{M}$, or in the water solution of phytohormone auxin IAA used at the same concentration $10^{-8} \mathrm{M}$. To perform extraction of pigments the sample $\left(500 \mathrm{mg}\right.$ ) of leaves isolated from $6^{\text {th }}$-week-old wheat (Triticum aestivum L.) seedlings was homogenized in the porcelain mortar in a cooled at the temperature $10{ }^{\circ} \mathrm{C} 96 \%$ ethanol at the ratio of $1: 10$ (weight: volume) with addition of $0,1-0,2 \mathrm{~g} \mathrm{CaCO} 3$ (to neutralize the plant acids). The $1 \mathrm{ml}$ of obtained homogenate was centrifuged at $8000 \mathrm{~g}$ in a refrigerated centrifuge K24D (MLW, Engelsdorf, Germany) during 5 min at the temperature $4{ }^{\circ} \mathrm{C}$. The obtained precipitate was washed three times, with $1 \mathrm{ml} 96 \%$ etanol and centrifuged at above mentioned conditions. After this procedure, the optical density of chlorophyll $a$, chlorophyll $b$ and carotenoid in the obtained extract was measured using spectrophotometer Specord M-40 (Carl Zeiss, Germany).

The content of chlorophyll a, chlorophyll b, and carotenoids was calculated in accordance with formula [71]:

$$
\begin{aligned}
& \text { Cchl } a=13.36 \times A 664.2-5.19 \times A 648.6, \\
& C c h l b=27.43 \times A 648.6-8.12 A \times 664.2, \\
& C c h l(a+b)=5.24 \times A 664.2+22.24 \times A 648.6, \\
& C c a r=(1000 \times A 470-2.13 \times C c h l a-97.64 \times C \text { chlb }) / 209,
\end{aligned}
$$

Where, Cchl - concentration of chlorophylls $(\mathrm{mg} / \mathrm{ml})$, Cchl a- concentration of chlorophyll a $(\mathrm{mg} / \mathrm{ml}), \mathrm{Cchl} b-$ concentration of chlorophyll b $(\mathrm{mg} / \mathrm{ml})$, Ccar - concentration of carotenoids $(\mathrm{mg} / \mathrm{ml}), \mathrm{A}-$ absorbance value at a proper wavelength in $\mathrm{nm}$.

The chlorophyll and carotenoids content per $1 \mathrm{~g}$ of fresh weight (FW) of extracted from wheat leaves was calculated by the following formula (separately for chlorophyll a, chlorophyll $b$ and carotenoids):

$$
A_{1}=(C \times V) /\left(1000 \times a_{1}\right),
$$

Where, $A_{1}$ - content of chlorophyll a, chlorophyll b, or carotenoids (mg/g FW), C - concentration of pigments $(\mathrm{mg} / \mathrm{ml}), \mathrm{V}$ - volume of extract $(\mathrm{ml}), \mathrm{a}_{1}$ - sample of plant tissue $(\mathrm{g})$.

The content of chlorophyll a, chlorophyll b, and carotenoids determined in the leaves of the $6^{\text {th }}$-week-old wheat seedlings grown in the water solution of synthetic LMWHC, pyrazole derivatives used at the concentration $10^{-}$ ${ }^{8} \mathrm{M}$ was calculated in \% according to similar indices determined in the leaves of control $6^{\text {th }}$-week-old wheat 
seedlings grown in the distilled water, or in the water solution of phytohormone auxin IAA used at the same concentration $10^{-8} \mathrm{M}$.

\subsection{Statistical Analysis}

All experiments were performed in three replicates. Statistical analysis of the data was performed using dispersive Student's-t test with the level of significance at $\mathrm{P} \leq 0.05$; the values are mean \pm SD [72].

\section{Results and Discussion}

\subsection{Impact of pyrazole derivatives on morphometric parameters of wheat seedlings}

The conducted researchers showed that synthetic LMWHC, pyrazole derivatives used at the concentration $10^{-}$ ${ }^{8} \mathrm{M}$ revealed auxin-like stimulating effect on growth and development of the roots and shoots of wheat (Triticum aestivum L.) seedlings cultivar Antonivka during the six weeks (Fig. 1).

A

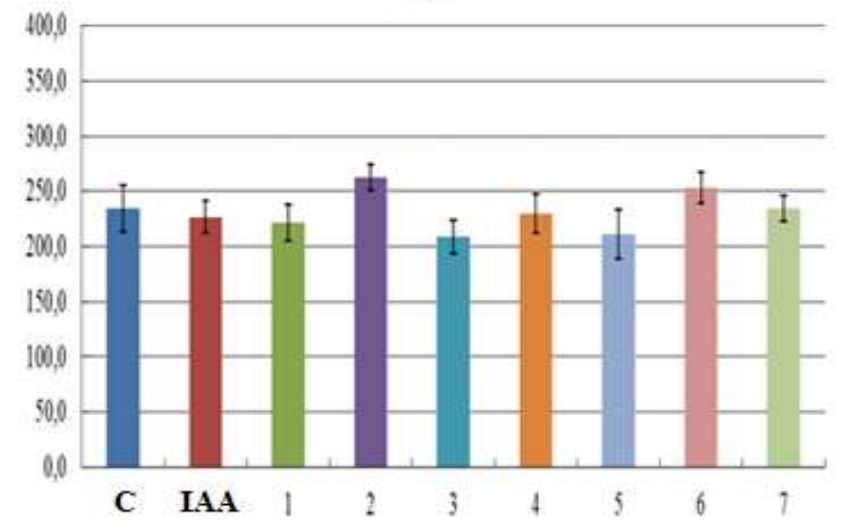

C

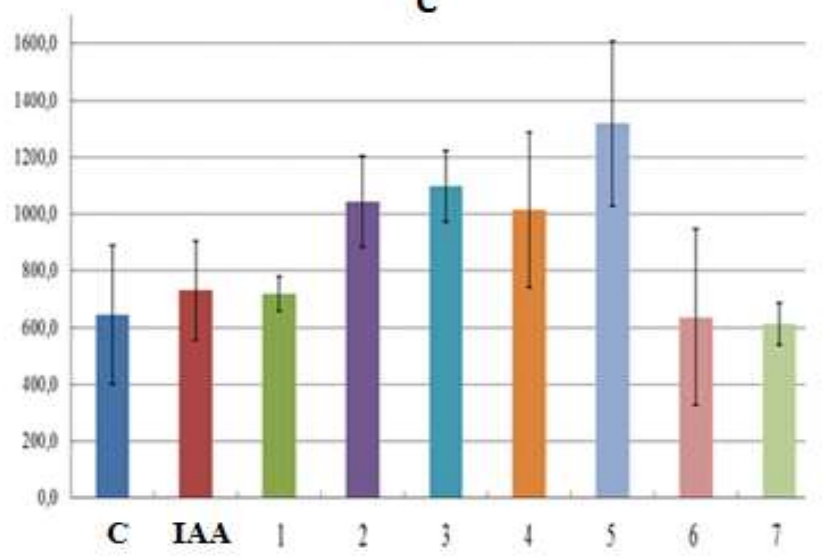

B

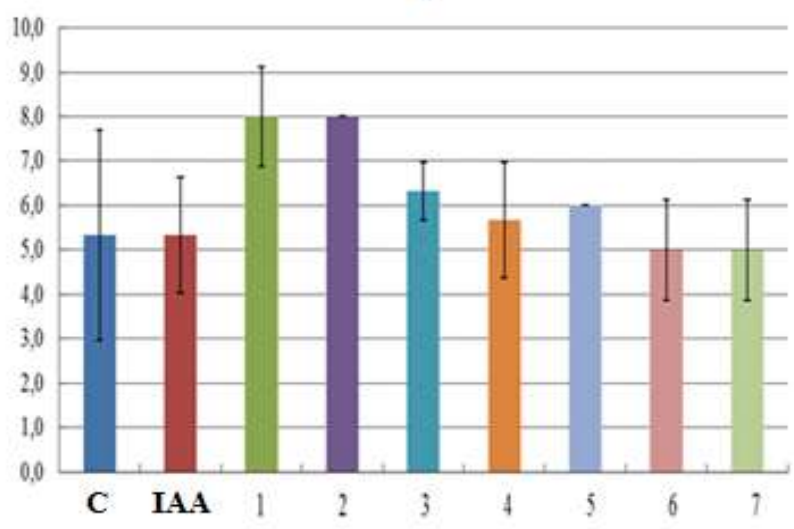

D

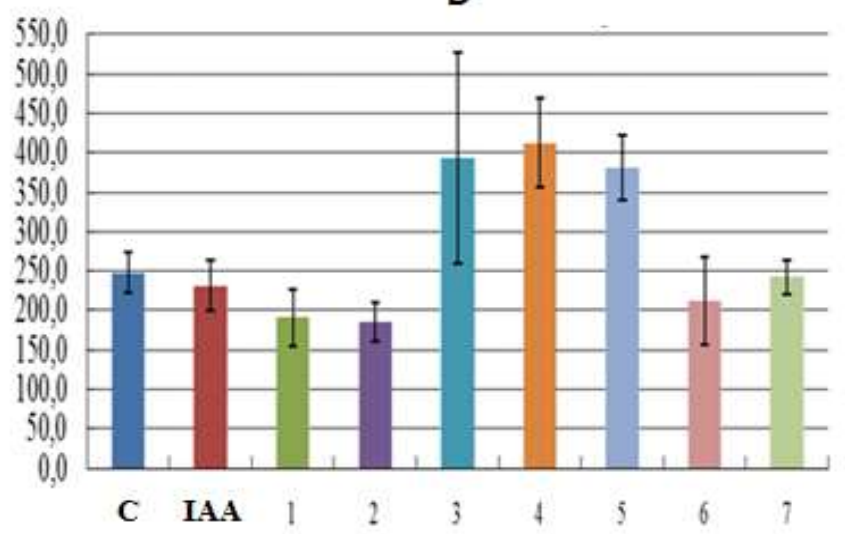

Fig. 1. Effect of synthetic LMWHC, pyrazole derivatives (compounds № 1-7) and plant hormone auxin IAA (1HIndol-3-ylacetic acid) used at the concentration $10^{-8} \mathrm{M}$ on morphometric parameters of the roots and shoots of wheat (Triticum aestivum L.) seedlings cultivar Antonivka during the 6 weeks as compared with morphometric parameters of the roots and shoots of control wheat seedlings grown in the distilled water (C). A - length of shoots (mm); B - total number of roots (pcs); C - total length of roots (mm); D - length of the longest root (mm)

Among tested synthetic $\mathrm{LMWHC}$, pyrazole derivatives, the highest stimulating activity on growth and development of the wheat seedlings revealed the compounds № 2, 3, 4 and 5. 
The morphometric parameters of the $6^{\text {th }}$-week-old wheat seedlings grown in the water solution of the compounds № 2, 3, 4 and 5 used at the concentration $10^{-8} \mathrm{M}$ were similar or higher to the morphometric parameters of the wheat seedlings grown in the distilled water (control) or water solution of auxin IAA used at the same concentration $10^{-8} \mathrm{M}$ on average: to $31-54 \%$ - for total number of roots, to $39-104 \%$ - for total length of roots, to $53-66 \%$ - for length of the longest root (Fig. 1).

\subsection{Impact of pyrazole derivatives on the content of photosynthetic pigments in wheat seedlings}

We conducted the comparative analysis of the effect of synthetic LMWHC, pyrazole derivatives and phytohormone auxin IAA on content in the leaves of wheat (Triticum aestivum L.) seedlings cultivar Antonivka of the photosynthetic pigments (chlorophyll $a$, chlorophyll $b$, and carotenoids) ensuring wheat productivity [73 - 76]. Plant hormones cytokinins are known to play an important role in the biosynthesis of photosynthetic pigments such as chlorophylls and carotenoids and delayed degradation of chlorophylls in plant cells [77 - 79].

The obtained results showed the cytokinin-like stimulating effect of synthetic LMWHC, pyrazole derivatives used at the concentration $10^{-8} \mathrm{M}$ on increasing of content $(\mathrm{mg} / \mathrm{ml}$ ) of photosynthetic pigments (chlorophyll a, chlorophyll $b$, and carotenoids) in the leaves of wheat (Triticum aestivum L.) seedlings cultivar Antonivka grown during the 6 weeks (Fig. 2).

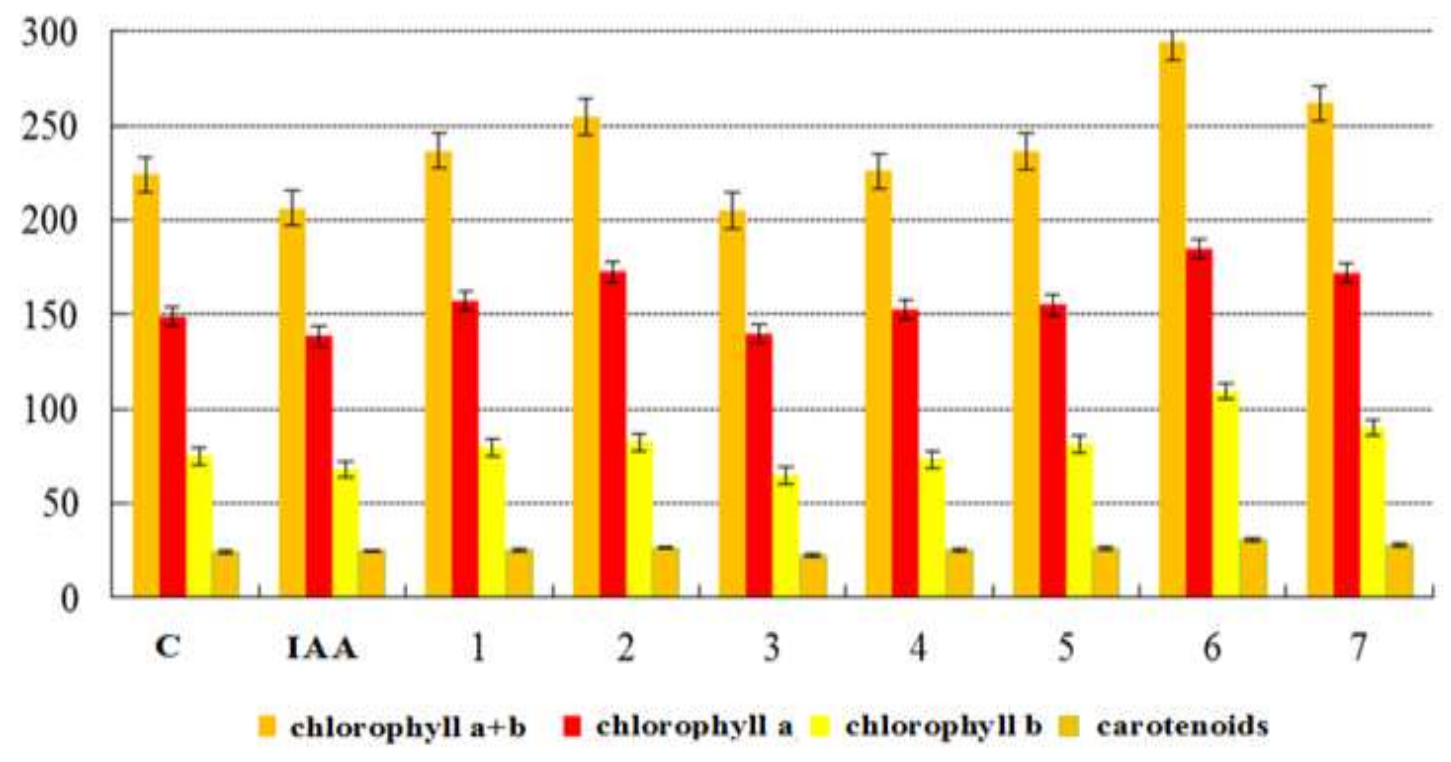

Fig. 2. Effect of synthetic $L M W H C$, pyrazole derivatives (compounds № 1-7) and plant hormone auxin IAA (1HIndol-3-ylacetic acid) used at the concentration $10^{-8} \mathrm{M}$ on content $(\mathrm{mg} / \mathrm{ml})$ of chlorophyll a, chlorophyll b and carotenoids in the leaves of wheat (Triticum aestivum L.) seedlings cultivar Antonivka grown during the six weeks

Among tested synthetic LMWHC, pyrazole derivatives, the highest stimulating activity on the content of photosynthetic pigments in the leaves of wheat seedlings revealed the compounds № 2, 6 and 7 . The content of chlorophyll $a$ in the leaves of wheat seedlings grown in the water solution of the compounds № 2, 6 and 7 used at the concentration $10^{-8} \mathrm{M}$ increased on average at the $15-34 \%$, respectively, as compared with content of photosynthetic pigments in the leaves of wheat seedlings grown on the distilled water (control), or on the water solution of auxin IAA used at similar concentration $10^{-8} \mathrm{M}$ (Fig. 2).

The content of chlorophyll $b$ in the leaves of wheat seedlings grown in the water solution of the compounds № 2, 6 and 7 used at the concentration $10^{-8} \mathrm{M}$ increased on average at the $10-61 \%$, respectively, as compared with content of photosynthetic pigments in the leaves of wheat seedlings grown on the distilled water (control), or on the water solution of auxin IAA used at similar concentration $10^{-8} \mathrm{M}$ (Fig. 2). 
The content of chlorophylls $a+b$ in the leaves of wheat seedlings grown in the water solution of the compounds № 2, 6 and 7 used at the concentration $10^{-8} \mathrm{M}$ increased on average at the $16-34 \%$, respectively, as compared with content of photosynthetic pigments in the leaves of wheat seedlings grown on the distilled water (control), or on the water solution of auxin IAA used at similar concentration $10^{-8} \mathrm{M}$ (Fig. 2).

The content of carotenoids in the leaves of wheat seedlings grown in the water solution of the compounds № 2,6 and 7 used at the concentration $10^{-8} \mathrm{M}$ increased on average at the $14-28 \%$, respectively, as compared with content of photosynthetic pigments in the leaves of wheat seedlings grown on the distilled water (control), or on the water solution of auxin IAA used at similar concentration $10^{-8} \mathrm{M}$ (Fig. 2).

Obviously, the cytokinin-like effect of pyrazole derivatives is associated with an increase in the synthesis of photosynthetic pigments such as chlorophylls and carotenoids and delayed degradation of chlorophylls in plant cells [77 - 79].

Thus, the conducted studies have shown that synthetic LMWHC, pyrazole derivatives revealed a uxin-like and cytokinin-like stimulating effect on growth and development of wheat (Triticum aestivum L.) seedlings cultivar Antonivka during the 6 weeks.

It is possible to assume that the molecular mechanisms of action of these synthetic LMWHC, pyrazole derivatives might be associated with their regulatory action (by analogy with plant hormone auxin) on the network of key auxin-binding proteins (ABPs) that may be the auxin receptors involved in auxin signalling and transport, network of auxin response transcription factors (ARFs) that are DNA-binding proteins, which recognize and bind to auxin responsive cis-acting promoter elements (AuxREs) in early/primary auxin response genes, and network of transcription factors that bind to promoter elements in genes encoding protein-enzymes responsible for plant cell division and extension [80 - 103].

Otherwise, there could be an alternative mode of action related to the inhibitory effect of synthetic LMWHC, pyrazole derivatives on the activity of a key enzyme IAA-oxidase, which is involved in the enzymatic destruction (degradation) of auxin [104]. As a result, the level of endogenously synthesized auxin IAA is increased in the plant cells, and auxin transport, perception, and signaling are restored leading to improved plant cell division and extension that are the main processes of plant growth and development [ $80-103]$. Obviously also, that the cytokinin-like effect of synthetic LMWHC, pyrazole derivatives can be related to their direct influence on the metabolism of endogenous plant hormones or their inhibitory effect on the activity of an enzyme cytokinin oxidase, which is involved in the enzymatic destruction (degradation) of endogenous plant cytokinins [105]. As a result, the level of endogenously synthesized cytokinins is increased in the plant cells, and cytokinin transport, perception and signal transduction are restored $[106,107]$ leading to improved plant cell division and increased synthesis of photosynthetic pigments such as chlorophylls and carotenoids, and delayed leaf senescence [77 - 79].

In support of the bottom concept indicate published works $[108,109]$ which showed the effect of exogenously applied synthetic analogs of auxin on the decrease in the activity of IAA-oxidase and vice versa on the increase in the level of synthesis of endogenous auxin IAA in plant cells.

The authors of the work [110] also suggested that synthetic auxins might affect the level of synthesis of endogenous auxin modifying directly synthesis of enzyme IAA-oxidase and indirectly through effectors of IAAoxidase.

Similar studies were conducted in work [111] that showed that synthetic 2-R substituted benzothiazole derivatives demonstrated dominant auxin-like plant growth promoting activity. Based on obtained results, showing that the plant growth promoting activity of synthetic benzothiazole compounds can be correlated with the activity of IAA synthetase, the authors have proposed that the mode of action of synthetic 2-R substituted benzothiazole derivatives as auxin-like substances is due to their possible regulation of synthesis or degradation of endogenous auxin indole-3-acetic acid (IAA) in plants. The assumptions discussed in the works [108 - 111] 
are consonant with our early published work [112], which testified in favor of the indirect, mediated through endogenous phytohormones action of synthetic LMWHC, derivatives of pyridine - lutidine $\mathrm{N}$-oxide (Ivin) and pyrimidine - 6-methylthiouracil (Methyur) on plant cell extension, and published works of other authors [113 118] that showed the effect of exogenously applied synthetic multi-dimensional plant growth regulator Thidiazuron (TDZ; N-phenyl-1,2,3-thidiazole-5ylurea) on increase in concentrations of endogenous cytokinins, auxin, ethylene and ABA in plant cells. Authors of work [117] suggested that the powerful cytokinin-like regulatory effect of TDZ on plant growth is associated with its influence on the metabolism of endogenous plant hormones, either directly or indirectly through prevention the breakdown of endogenous purines by inhibiting cytokinin oxidase, due to which plant cell division and regeneration occur.

\section{Conclusion}

The conducted comparative analysis of the plant growth regulatory activity of synthetic LMWHC; pyrazole derivatives showed that tested synthetic compounds used at the concentration used at the concentration $10^{-}$ ${ }^{8} \mathrm{M}$ revealed auxin-like and cytokinin-like stimulating effect ont he growth of wheat (Triticum aestivum L.) seedlings cultivar Antonivka during the six weeks. It was found that plant growth regulatory activity of tested synthetic LMWHC; pyrazole derivatives was similar or higher of the activity of $\mathrm{plant} h$ ormone auxin IAA used at the same concentration $10^{-8} \mathrm{M}$. It was found that the plant growth regulatory activity of synthetic LMWHC, pyrimidine derivatives was varied depending on their chemical structure. Among tested chemical compounds, the highest activity by the plant morphometric parameters revealed the compounds № 2, 3, 4 and 5, while the highest activity by the content of chlorophylls and carotenoids revealed the compounds № 2, 6 and 7. The obtained results confirmed the possibility of the practical application of pyrazole derivatives as new effective substitutes for plant hormones for regulating the growth and development of wheat (Triticum aestivum L.) plants during the vegetative stage.

\section{Conflict of interest}

Authors stated that there is no conflict of interest.

\section{References}

1. Lam-Son T., Sikander P. (Eds.). (2014): Phytohormones: A Window to Metabolism, Signaling and Biotechnological Applications, Springer-Verlag, New York, 361 p.

2. Wania S.H., Kumarb V., Shriramc V., Sah S.K. (2016): Phytohormones and their metabolic engineering for abiotic stress tolerance in crop plants. The crop journal, 4: 162-176.

3. Erb M., Glauser G. (2010): Family business: multiple members of major phytohormone classes orchestrate plant stress responses. Chem. A Eur. J., 16(34): 10280-10289.

4. Javid M.G., Sorooshzadeh A., Moradi F., Sanavy S.A.M.M., Allahdadi I. (2011): The role of phytohormones in alleviating salt stress in a crop plant. Australian Journal of Crop Science (AJCS), 5(6): 726-734.

5. Pieterse C.M.J., Vander Does D., Zamioudis C., Leon-Reyes A., and VanWees S.C.M. (2012): Hormonal Modulation of Plant Immunity. Annual Review of Cell and Developmental Biology, 28: 489-521.

6. Denancé N., Sánchez-Vallet A., Goffner D. and Molina A. (2013): Disease resistance or growth: the role of plant hormones in balancing immune responses and fitness costs. Frontiers in Plant Science, Plant Cell Biology, 4 (Article155): 1-12.

7. Rahman A. (2013): Auxin: a regulator of the cold stress response. Physiologia Plantarum, 147: 28-35.

8. Tuteja N. (2007): Abscisic Acid and Abiotic Stress Signaling. Plant Signal Behav, 2(3): 135-138. 
9. Ahmad P., Rasool S., Gul A., Sheikh S.A., Akram N.A., Ashraf M. (2016): Jasmonates: Multifunctional Roles in Stress Tolerance. Front Plant Sci, 7: 813.

10. Yusuf M., Khan T.A., Fariduddin Q. (2017): Brassinosteroids: Physiological Roles and its Signalling in Plants. In: Stress Signaling in Plants: Genomics and Proteomics Perspective, Sarwat M., AhmadA., Abdin M.Z., Ibrahim, M.M. (Eds.), Springer International Publishing, 2: pp. 241-260.

11. Hayat S. and Ahmad A. (Eds.). (2003): Brassinosteroids: Bioactivity and Crop Productivity, Springer Netherlands, XIII: 246 p.

12. Vlot A.C., Dempsey D.A., and Klessig D.F. (2009): Salicylic Acid, a Multifaceted Hormone to Combat Disease. Annu. Rev. Phytopathol, 47: 177-206.

13. Vicente M.R.S. and Plasencia J. (2011): Salicylic acid beyond defence: its role in plant growth and development, Journal of Experimental Botany, 62(10): 3321-3338.

14. Basra A.S. (Ed). (2000): Plant Growth Regulators in Agriculture and Horticulture: Their Role and Commercial Uses. Haworth Press, Inc., New York, London, Oxford, 264 p.

15. Rademacher W. (2015): Plant growth regulators: backgrounds and uses in plant production. J P I a n t Growth Regul, 34(4): 845-872.

16. Meena O.P. (2015): A review: role of plant growth regulators in vegetable production. International Journal of Agricultural Science and Research (IJASR), 5(5): 71-84.

17. Lopez-lauri F. (2016): Plant Growth Regulators. In: Siddiqui M.W., Zavala A., Hwang J.F., Andy C. (Eds.) Postharvest Management Approaches for Maintaining Quality of Fresh Produce, Springer International Publishing, Switzerland, 125-139 pp.

18. Jardin P. (2015): Plant biostimulants: Definition, concept, main categories, and regulation, Sci. Hortic, 196 (30): 3-14.

19. Le Mire G., Nguyen M.L., Fassotte B., Jardin P., Verheggen F., Delaplace P., Jijakli M.H. (2016): Implementing plant biostimulants and biocontrol strategies in the agroecological management of cultivated ecosystems. A review. Biotechnol. Agron. Soc. Environ, 20(S1): 299-313.

20. Calvo P., Nelson L., Kloepper J.W. (2014): Agricultural uses of plant biostimulants. Plant Soil, 383(1): 341.

21. Tsygankova V.A., Ponomarenko S.P., Hrytsaenko Z.M. (2012): Increase of plant resistance to diseases, pests, and stresses with new biostimulants. Acta Horticulturae: I World Congress on the Use of Biostimulants in Agriculture, Strasburg (France), 1009: 225-233.

22. Tsygankova V.A., lutynska G.A., Galkin A.P., Blume Ya.B. (2014): Impact of New Natural Biostimulants on Increasing Synthesis in Plant Cells of Small Regulatory si/miRNA with High Anti-Nematodic Activity. Internat. J. Biol, 6(1): 48-64.

23. Bhardwaj D., Ansari M.W., Sahoo R.K., and Tuteja N. (2014): Biofertilizers function as a key player in sustainable agriculture by improving soil fertility, plant tolerance, and crop productivity. Microbial Cell Factories, 13: 66: 1-10.

24. Rejeb I.B., Pastor V. and Mauch-Mani B. (2014): Plant Responses to Simultaneous Biotic and Abiotic Stress: Molecular Mechanisms. Plants, 3: 458-475. 
25. Dresselhaus, T., and Hückelhoven R. (2018): Biotic and Abiotic Stress Responses in Crop Plants. Agronomy, 8: 267.

26. Doughari J.H. (2015): An Overview of Plant Immunity. J Plant Pathol Microbiol, 6 (11): 322.

27. Gimenez E., Salinas M. and Manzano-Agugliaro F. (2018): Worldwide Research on Plant Defense against Biotic Stresses as Improvement for Sustainable Agriculture. Sustainability, 10: 391.

28. Cansev A., Gulen H., Zengin M.K., Ergin S., Cansev M., Kumral N.A. (2016): Use of pyrimidines in the stimulation of plant growth and development and enhancement of stress tolerance, Patent 20160000075.

29. Corsi C., Wendeborn S.V., Bobbio C., Kessabi J., Schneiter P., Grasso V., Haas U.J. (2011): Isothiazole and pyrazole derivatives for use as plant growth regulators, Patent EP 2358699A1.

30. Newton T., Waldeck I. (2000): Oxazole carboxamide herbicides, Patent US6096688 A.

31. Nimbalkar S., Hote S.V. (2015): Pyrazole Derivatives and their Synthesis - A review. International Journal on Recent and Innovation Trends in Computing and Communication, 3(2): 61-65.

32. Whittingham W.G., Winn C.L., Glithro H., Boussemghoune M.A., Aspinall M.B. (2010): Pyrimidine derivatives and their use as herbicides, Patent WO2010092339 A1.

33. Minn K., Dietrich H., Dittgen J., Feucht D., Häuser-Hahn I., Rosinger C.H. (2008): Pyrimidine derivatives and their use for controlling undesired plant growth, Patent US 8329717 B2.

34. Kuragano T., Tanaka Y. (2002): Dérivés de la pyrimidine et herbicides les contenant, Patent WO 2002038550 A1.

35. Takahashi A., Yamada S., Yamada H., Kawana T. (2001): Mitotic disruption by a novel pyrimidine herbicide, NS-245852, in oat (Avena sativa L.) roots. Weed Biology and Management, 1(3): 1.

36. Stuart A.L., Ayisi N.K., Tourigny G., Gupta V.S. (1985): Antiviral activity, antimetabolic activity, and cytotoxicity of 3'-substituted deoxypyrimidine nucleosides. Journal of Pharmaceutical Sciences, 74(3): 246-249.

37. Jain K.S., Chitre T.S., Miniyar P.B., Kathiravan M.K., Bendre V.S., Veer V.S., Shahane S.R., Shishoo C.J. (2006): Biological and medicinal significance of pyrimidines. Curr Sci, 90(6): 793-803.

38. Jain K.S., Arya N., Inamdar N.N., Auti P.B., Unawane S.A., Puranik H.H., Sanap M.S., Inamke A.D., Mahale V.J., Prajapati C.S., Shishoo C.J. (2016): The Chemistry and Bio-Medicinal Significance of Pyrimidines \& Amp; Condensed Pyrimidines. Curr Top Med Chem, 16(28): 3133-3174.

39. Galmarini C.M., Jordheim L., Dumontet C. (2003): Pyrimidine nucleoside analogs in cancer treatment. Expert Rev Anticancer Ther, 3(5): 717-728.

40. Parker W.B. (2009): Enzymology of purine and pyrimidine antimetabolites used in the treatment of cancer. Chemical reviews, 109(7): 2880.

41. Kumar R., Arora J., Prasad A.K., Islam N., Verma A.K. (2013): Synthesis and antimicrobial activity of pyrimidine chalcones. MCRE, 22(11): 5624-5631.

42. Kumar R., Arora J., Ruhil S., Phougat N., Chhillar A.K., Prasad A.K. (2014): Synthesis and Antimicrobial Studies of Pyrimidine Pyrazole Heterocycles. Advances in Chemistry, Article ID 329681, 1-12.

43. Raghunat, S.A., Manjunatha Y., and Rayappa K. (2012): Synthesis, antimicrobial, and antioxidant activities 
of some new indole analogues containing pyrimidine and fused pyrimidine systems. Med Chem Res, 21(11): 3809-3817.

44. Quin L.D., Tyrell J.A. (2010): Fundamentals of heterocyclic chemistry: Importance in Nature and in the Synthesis of Pharmaceuticals, John Wiley \& Sons, Inc., Hoboken, New Jersey, 344 p.

45. Shiferaw B., Smale M., Braun H.J., Duveiller E., Reynolds M., Muricho G. (2013): Crops that feed the world. 10. Past successes and future challenges to the role played by wheat in global food security. Food Sec., 5(3): 291-317.

46. Reynolds M., Bonnett D., Chapman S., Furbank R., Mane` Ya, Mather D., Parry M. (2011): Raising yield potential of wheat. I. Overview of a consortium approach and breeding strategies. J Exp Bot. 62: 439-452.

47. Faltermaier A., Waters D., Becker T., Arendt E. and Gastl M. (2014): Common wheat (Triticum aestivum L.) and its use as a brewing cereal - a review. J. Inst. Brew.. 120: 1-15.

48. Pathak V., Shrivastav S. (2015): Biochemical studies on wheat (Triticum aestivum L.). Journal of Pharmacognosy and Phytochemistry, 4(3): 171-175.

49. World Population Prospects, the 2015 Revision. United Nations, New York, 2015.

50. Barányiová I., Klem K. (2016): Effect of application of growth regulators on the physiological and yield parameters of winter wheat under water deficit. Plant Soil Environ, 62(3): 114-120.

51. Laghari G.M., Oad F.C., Tunio S., Gandahi A.W., Siddiqui M.H., Jagirani A.W. and Oad S.M. (2010): Growth, yield and nutrient uptake of various wheat cultivars under different fertilizer regimes. Sarhad J. Agric., 26(4): 489-497.

52. Barányiová I., Klem K., Kren J. (2014): Effect of exogenous application of growth regulators on the physiological parameters and the yield of winter wheat under drought stress. Proc. of Int. Ph.D. Students Conf. At: Mendel University in Brno, Faculty of Agronomy, Czech Repoublic, 2014: 442-446.

53. Shekoofa, A., Emam Y. (2008): Effects of Nitrogen Fertilization and Plant Growth Regulators (PGRs) on Yield of Wheat (Triticum aestivum L.) cv. Shiraz. J. Agric. Sci. Technol., 10: 101-108.

54. Singh A., Brar K.S., Singh S. and Gandhi N. (2019): Effect of different organic, inorganic and bio-fertilizer on the yield and yield components of wheat. Journal of Pharmacognosy and Phytochemistry, 8(4): 4-6.

55. Bukowska B. (2006): Toxicity of 2,4-Dichlorophenoxyacetic Acid - Molecular Mechanisms. Polish J Environ Stud, 15(3): 365-374.

56. Celik I., Tuluce Y. (2007): Determination of toxicity of subacute treatment of some plant growth regulators on rats. Environ Toxicol, 22(6): 613-619.

57. Hąc-Wydro K., Flasiński M. (2015): The studies on the toxicity mechanism of environmentally hazardous natural (IAA) and synthetic (NAA) auxin- the experiments on model Arabidopsis thaliana and rat liver plasma membranes. Colloids Surf B Biointerfaces, 130: 53-60.

58. Thomason, I. A. (1987): "Challenges facing nematology: Environmental risks with nematicides and the need for new approaches," in Vistas on Nematology, J. A. Weech and D. W. Dickson (Eds), Hyattsville, MD: Society of Nematologists, 469-476.

59. Aktar M.W., Sengupta D. and Chowdhury A. (2009): Impact of pesticides use in agriculture: their benefits and hazards. Interdiscip Toxicol, 2(1): 1-12; 
60. Alewu B. and Nosiri C. (2011): Pesticides and Human Health, Pesticides in the Modern World - Effects of Pesticides Exposure, M. Stoytcheva (Ed.), InTechOpen.

61. Nicolopoulou-Stamati P., Maipas S., Kotampasi C., Stamatis P., Hens L. (2016): Chemical Pesticides and Human Health: The Urgent Need for a New Concept in Agriculture. Front Public Health, 4: Article 148.

62. Tsygankova V., Andrusevich Ya., Shtompel O., Romaniuk O., Yaikova M., Hurenko A., Solomyanny R., Abdurakhmanova E., Klyuchko S., Holovchenko O., Bondarenko O., Brovarets V. (2017): Application of Synthetic Low Molecular Weight Heterocyclic Compounds Derivatives of Pyrimidine, Pyrazole and Oxazole in Agricultural Biotechnology as a New Plant Growth Regulating Substances. Int J Med Biotechnol Genetics, S2:002: 10-32.

63. Tsygankova V.A., Andrusevich Ya.V., Shtompel O.I., Kopich V.M., Pilyo S.G., Prokopenko V.M, Kornienko A.M, Brovarets V.S. (2017): Intensification of Vegetative Growth of Cucumber by Derivatives of [1,3] oxazolo[5,4d]pyrimidine and $\mathrm{N}$-sulfonyl substituted of 1,3-oxazole. Research Journal of Life Sciences, Bioinformatics, Pharmaceutical, and Chemical Sciences (RJLBPCS), 3(4): 107-122.

64. Tsygankova V., Andrusevich Ya., Kopich V., Shtompel O., Pilyo S., Kornienko A.M, Brovarets V. (2018): Use of Oxazole and Ox azolopyrimidine to Improve Oilseed Rape Growth. Scholars Bulletin, 4(3): 301-312.

65. Tsygankova V.A., Andrusevich Ya.V., Shtompel O.I., Pilyo S.G., Kornienko A.M., Brovarets V.S. (2018): Using of [1,3]oxazolo[5,4-d]pyrimidine and $\mathrm{N}$-sulfonyl substituted of 1,3-oxazole to improve the growth of soybean seedlings. Chemistry Research Journal, 3(2): 165-173.

66. Tsygankova V.A., Andrusevich Ya.V., Shtompel O.I., Pilyo S.G., Kornienko A.M., Brovarets V.S. (2018): Acceleration of vegetative growth of wheat (Triticum aestivum L.) using [1,3] oxazolo[5,4-d] pyrimidine and $\mathrm{N}$-sulfonyl substituted 1,3-oxazole. The Pharmaceutical and Chemical Journal, 5(2): 167-175.

67. Tsygankova V.A., Andrusevich Ya.V., Shtompel O.I., Shablykin O.V., Hurenko A.O., Solomyanny R.M., Mrug G.P., Frasinyuk M.S., Pilyo S.G., Kornienko A.M., Brovarets V.S. (2018): Auxin-like effect of derivatives of pyrimidine, pyrazole, isoflavones, pyridine, oxazolopyrimidine, and oxazole on the acceleration of vegetative growth of flax. International Journal of PharmTech Research, 11(3): 274-286.

68. Tsygankova V.A., Andrusevich Ya.V., Shtompel O.I., Solomyanny R.M., Hurenko A.O., Frasinyuk M.S., Mrug G.P., Shablykin O.V., Pilyo S.G., Kornienko A.M., Brovarets V.S. Study of auxin-like and cytokinin-like activities of derivatives of pyrimidine, pyrazole, isoflavones, pyridine, oxazolopyrimidine and oxazole on haricot bean and pumpkin plants, International Journal of ChemTech Research, 2018, 11(10): 174-190.

69. Tsygankova V., Andrusevich Ya., Shtompel O., Kopich V., Solomyanny R., Bondarenko O., Brovarets V. (2018): Phytohormone-like effect of pyrimidine derivatives on the regulation of vegetative growth of tomato. International Journal of Botany Studies, 3(2): 91-102.

70. Voytsehovska O.V., Kapustyan A.V., Kosik O.I., Musienko M.M., Olkhovich O.P., Panyuta O.O., Parshikova T.V., Glorious P.S. (2010): Plant Physiology: Praktykum, Lutsk: Teren.

71. Lichtenthaler H. (1987): Chlorophylls and Carotenoids: Pigments of Photosynthetic Biomembranes. Methods Enzymol, 148: 331-382.

72. Bang H., Zhou X.K, van Epps H.L., Mazumdar M. (2010): Statistical Methods in Molecular Biology, Series: Methods in molecular biology, New York: Humana press.

73. Lodish H, Berk A, Zipursky SL, Matsudaira P, Baltimore D, Darnell J. (2000): Molecular Cell Biology. Section 16.3, Photosynthetic Stages and Light-Absorbing Pigments, $4^{\text {th }}$ Ed. W.H. Freeman and Company, 
New York, USA.

74. Cazzonelli C.I. (2011): Carotenoids in nature: insights from plants and beyond. Functional Plant Biology, 38 : 833-847.

75. Sabo M., Teklic T., Vidovic I. (2002): Photosynthetic productivity of two winter wheat varieties (Triticum aestivum L.). ROSTLINNÁ VÝROBA, 48 (2): 80-86.

76. Priadkina H.O. (2018): Pigments, the efficiency of photosynthesis, and winter wheat productivity. Plant Varieties Studying and protection, 14(1): 97-108.

77. Mok D.W.S., Mok M.C. (2001): Cytokinin metabolism and action. Annu. Rev. Plant Physiol. Plant Mol. Biol. 52: 89-118.

78. Zwack P.J., Rashotte A.M. (2013): Cytokinin inhibition of leaf senescence. Plant Signaling \& Behavior. 8(7): e24737.

79. Hönig M., Plíhalová L., Husicková A., Nisler J. and Doležal K. (2018): Role of Cytokinins in Senescence, Antioxidant Defenc, and Photosynthesis. Int. J. Mol. Sci., 19(4045): 1-23.

80. Woodward A.W., Bartel B. (2005): Auxin: regulation, action, and interaction. Ann Bot, 95(5): 707-735.

81. Zhao Yu. (2010): Auxin biosynthesis and its role in plant development. Annu Rev Plant Biol, 61: 49-64.

82. Sauer M., Robert S., Kleine-Vehn J. (2013): Auxin: simply complicated. J Exp Bot, 64(9): 2565-2577.

83. Enders T.A., Strader L.C. (2015): Auxin activity: Past, present, and future. Am J Bot, 102(2): 180-196.

84. Woodward A.W., Bartel B. (2005): A receptor for auxin. Plant Cell, 17(9): 2425-2429.

85. Tsygankova V.A., Galkina L.A., Musatenko L.I., Sytnik K.M. (2005): Genetic and epigenetic control of plant growth and development. Molecular-genetic control of transmission and realization of auxin signals, Biopolym Cell, 21(3): 187-219.

86. Teale W.D., Paponov I., Palme K. (2006): Auxin in action: Signalling, transpor, and the control of plant growth and development. Nat Rev Mol Cell Biol, 7(11): 847-859.

87. Effendi Y., Scherer G.F. (2011): Auxin binding-protein1 (ABP1), a receptor to regulate auxin transport and early auxin genes in an interlocking system with PIN proteins and the receptor TIR1. Plant Signal Behav, 6(8): 1101-1103.

88. Hayashi K. (2012): The Interaction and Integration of Auxin Signaling Components. Plant and Cell Physiol, 53(6): 965-975.

89. Lavy M., Estelle M. (2016): Mechanisms of auxin signaling. Development, 143(18): 3226-3229.

90. Leyser O. (2017): Auxin Signaling, Plant Physiol, 176(1): 465-479.

91. Hagen G. and Guilfoyle T. (2002): Auxin-responsive gene expression: Genes, promoter, and regulatory factors. Plant Molecular Biology, 49(3-4): 373-85.

92. Chapman E.J. and Estelle M. (2009): Mechanism of Auxin-Regulated Gene Expression in Plants. Annu Rev Genet, 43: 265-285. 
93. Bouzroud S., Gouiaa S., Hu N., Bernadac A., Mila I., Bendaou N., Smouni A., Bouzayen M., Zouine M. (2018): Auxin Response Factors (ARFs) are potential mediators of auxin action in tomato response to biotic and abiotic stress (Solanum lycopersicum). PLoS ONE, 13(2): e0193517.

94. Tsygankova V.A. (2015): Genetic Control and Phytohormonal Regulation of Plant Embryogenesis. Int J Med Biotechnol Genetics (IJMBG), 3(1): 9-20.

95. Cherenkov P., Novikova D., Omelyanchuk N., Levitsky V., Grosse I., Weijers D., Mironova V. (2018): Diversity of cis-regulatory elements associated with auxin response in Arabidopsis thaliana. J Exp Bot, 69(2): 329-339.

96. Majda M., Robert S. (2018): The Role of Auxin in Cell Wall Expansion. Int J Mol Sci, 19(4): 951.

97. Catalá C., Rose J.K., Bennett A.B. (2000). Auxin-regulated genes encoding cell wall-modifying proteins are expressed during early tomato fruit growth. Plant Physiol, 122(2): 527-534.

98. Tsygankova V.A., Galkina L.A., Musatenko L.I., Sytnik K.M. Genetic and epigenetic control of plant growth and development. (2005): Genes of auxin biosynthesis and auxin-regulated genes controlling plant cell division and extension. Biopolym Cell, 21(2): 107-133.

99. Pop T.l., Pamfil D., Bellini C. (2011): Auxin Control in the Formation of Adventitious Roots, Not Bot Hort Agrobot Cluj, 39(1): 307-316.

100. Takatsuka H. and Umeda M. (2014): Hormonal control of cell division and elongation along differentiation trajectories in roots. Journal of Experimental Botany, 65(10): 2633-2643.

101. De Smet S., Cuypers A., Vangronsveld J. and Remans T. (2015): Gene Networks Involved in Hormonal Control of Root Development in Arabidopsis thaliana: A Framework for Studying Its Disturbance by Metal Stress. Int. J. Mol. Sci. 16: 19195-19224.

102. Shaul O., Van Montagu M., and Inze D. (1996): Cell Cycle Control in Arabidopsis. Annals of Botany, 78: 283288.

103. Komaki S. and Sugimoto K. (2012): Control of the Plant Cell Cycle by Developmental and Environmental Cues. Plant Cell Physiol, 53(6): 953-964.

104. Robert C. Hare. (1964): Indoleacetic Acid Oxidase. Botanical Review, 30(1): 129-165.

105. Avalbaev A.M., Somov K.A., Yuldashev R.A., Shakirova F.M. (2012): Cytokinin oxidase isa key enzyme of cytokinin degradation. Biochemistry (Mosc). 77(12): 1354-1361.

106. Kieber J. J., Schaller G.E. (2018): Cytokinin signaling in plant development. Development. 145 (dev149344): $1-7$.

107. Kieber, J. J., \& Schaller, G. E. (2014): Cytokinins. The Arabidopsis Book, 12, e0168.

108. Tandon P., Arya H.C. (1982): Association of Auxin Protectors, Peroxidase, Indoleacetic Acid Oxidas, and Polyphenol Oxidase in Zizyphus Gall and Normal Stem Tissues Grown in Culture. Biochemie und Physiologie der Pflanzen, 177(2): 114-124.

109. Liu Z.H., Hsiao I.C., and Pan Ya.W. (1996): Effect of naphthaleneacetic acid on endogenous indole-3-acetic acid, peroxidase and auxin oxidase in hypocotyl cuttings of soybean during root formation, Bot Bull Acad Sin, 37(4): 247-253. 
110. Gaspar T., Kevers C., Penel C., Greppin H., Reid D.M., Thorpe T.A. (1996): Plant hormones and plant growth regulators in plant tissue culture. In Vitro Cell Dev Biol Plant, 32(4): 272-289.

111. Šimonová E., Henselová M., Zahradník P. (2005): Benzothiazole derivatives substituted in position two as biologically active substances with plant growth regulation activity. Plant Soil Environ, 51: 496-505.

112. Tsygankova V.A., Zayets V.N., Galkina L.A., Blume Ya.B. (1999): The phytohormone-mediated action of the synthetic regulators on cell extension growth in higher plants. Biopolym Cell, 15(5): 432-441.

113. Yip W.K., Yang S.F. (1986): Effect of thidiazuron, a cytokinin-active urea derivative, in cytokinin-dependent ethylene production system. Plant Physiol, 80: 515-519.

114. Murthy B.N.S., Murch S.J., Saxena P.K. (1995): Thidiazuron-induced somatic embryogenesis in intact seedlings of peanut (Arachis hypogea): Endogenous growth regulator levels and significance of cotyledons. Physiol Plantarum, 94: 268-276.

115. Hutchinson M.J., Saxena P.K. (1996): Role of purine metabolism in thidiazuron-induced somatic embryogenesis of geranium (Pelargonium hortorum Bailey) hypocotyl cultures. Physiol Plantarum, 98: 517522.

116. Murthy B.N.S., Murch S.J., Saxena P.K. (1998): Thidiazuron: A potent regulator of in vitro plant morphogenesis. In Vitro Cell Dev Biol Plant, 34: 267-275.

117. Guo B., Abbasi B.H., Zeb A., Xu L.L., and Wei Y.H. (2011): Thidiazuron: A multi-dimensional plant growth regulator. AFR J BIOTECHNOL, 10(45): 8984-9000.

118. Naseem A., Mohammad F. (Eds.) (2018): Thidiazuron: From Urea Derivative to Plant Growth Regulator, Springer Singapore, $491 \mathrm{p}$. 